British Journal of Environment \& Climate Change

6(2): 64, 2016, Article no.BJECC.2016.006

ISSN: 2231-4784

SCIENCEDOMAIN international

www.sciencedomain.org

\title{
Part 1 - Climate Change Adaptation: Water Management and the Built Environment
}

\author{
Fayyaz Ali Memon ${ }^{1 *}$, J. O. Jenkins ${ }^{2}$ and B. Smyth ${ }^{3}$ \\ (Guest Editors) \\ ${ }^{1}$ Centre for Water System, College of Engineering, Mathematics, and Physical Sciences, \\ University of Exeter, Exeter, UK. \\ ${ }^{2}$ Associate Dean International, School of Life and Medical Sciences, University of Hertfordshire, \\ C P Snow Building, College Lane, Hatfield, Hertfordshire, AL10 9AB, UK. \\ ${ }^{3}$ School of Mechanical and Aerospace Engineering, Queen's University Belfast, Room 05.019, \\ Ashby Building, Stranmillis Road, Belfast BT9 5AH, UK.
}

Article Information

DOI: 10.9734/BJECC/2016/28295

Editorial

Received $13^{\text {th }}$ July 2016

Accepted $13^{\text {th }}$ July 2016

Published $13^{\text {th }}$ July 2016

A changing and more variable climate coupled with urbanization, population growth and shifting living standards has led towards increased frequency of extreme events (droughts and floods). Using water wisely in the built environment has the potential to enhance the resilience of urban water infrastructure to the extreme events.

This special issue consists of eight papers mainly focused on aspects of water management in the built environment (i.e. residential buildings). Topics covered, include: domestic water consumption trends, hot and cold water delivery systems, effectiveness of water efficiency measures in buildings, the role of rainwater harvesting, greywater recycling, and the impact of front gardens on attenuating flows and water quality. Sustainable water management in the built environment is the subject of renewed attention in many parts of the world, with public policy and the work of planners rapidly evolving and focusing on the implementation of decentralized and locally based solutions.

We hope readers will find the collection of presented papers informative, with them in turn contributing towards the development of new areas of research that lead to the development of relevant and impactful solutions. We would like to thank all contributing authors for their hard work and patience in the production of this special issue.

(C) 2016 Memon et al.; This is an Open Access article distributed under the terms of the Creative Commons Attribution License (http://creativecommons.org/licenses/by/4.0), which permits unrestricted use, distribution, and reproduction in any medium, provided the original work is properly cited.

${ }^{*}$ Corresponding author: E-mail: F.A.Memon@exeter.ac.uk;

Published in the $5^{\text {th }}$ Special Issue (Part 1) of British Journal of Environment \& Climate Change, 6(2): 2016, edited by Fayyaz Ali Memon, J. O. Jenkins and B. Smyth 